\title{
SOBRE A TEORIA DOS CUSTOS DOSDIREITOS
}

\author{
Josué Mastrodi ${ }^{1}$ \\ Abner Duarte Alves ${ }^{2}$
}

\begin{abstract}
Resumo
No presente artigo, temos por objetivo discutir a teoria dos custos dos direitos no âmbito dos direitos fundamentais. Segundo tal teoria, não há direitos se não houver recursos materiais para sua promoção. Em um ambiente de escassez de recursos e de necessidades humanas ilimitadas, deve-se prezar pela adequada administração e alocação dos recursos disponíveis. Afirma-se, nessa teoria, que alguns direitos fundamentais, os individuais, não geram custos para sua realização, de modo que a escassez de recursos impediria apenas a concretização de direitos sociais. No entanto, uma abordagem realista do Direito permite identificar que qualquer direito demanda custo, o que torna a teoria dos custos dos direitos refutável ao se constatar que sua finalidade, antes de descrever o Direito, é subordiná-lo a uma certa forma de organização social, promotora de alguns direitos fundamentais, mas não de outros.
\end{abstract}

Palavras-Chave: Custos dos Direitos. Direitos Fundamentais Sociais. Direitos Positivos/Negativos. Reserva do Possível. Mínimo Existencial.

\section{INTRODUÇÃO}

No presente artigo, temos por objetivo apresentar uma visão exploratória sobre a teoria dos custos dos direitos, adotando como estratégia operacional tratar topicamente sobre os diversos aspectos que tocam essa temática, sem perder de vista a interdependência e a co-implicação desses tópicos, visando à construção dos conceitos mais relevantes; procedemos este estudo tendo por base condições econômicas e considerações éticas (valores), bem como seus desdobramentos no mundo fático, em especial no que respeita à eficiência das instituições públicas responsáveis pela alocação e distribuição de recursos econômicos para promover os direitos fundamentais sociais, econômicos eculturais.

Para alcançar tal pretensão, buscamos excluir, na medida do possível, apreciações pessoais e estereótipos ideológicos e pautar nossa argumentação no âmbito da racionalidade jurídica. Não obstante, a busca pela cientificidade, em especial no campo das ciências humanas e sociais aplicadas, sempre denota certa opção

\footnotetext{
${ }^{1}$ Professor de Direito Civil da Faculdade de Direito da PUC-Campinas E-mail:mastrodi@puc-campinas.edu.br

${ }^{2}$ Bacharel em Direito pela PUC-Campinas. Graduando em Ciências Sociais pela Unicamp. E-mail: abner_duartealves@hotmail.com 
político-filosófica conforme o método adotado. Na presente situação, temos consciência de que não é diferente, em que pese nosso interesse pela objetividade.

Assim, nesta pesquisa, aproximamos o Direito da realidade concreta, identificando que a compreensão realista dos custos dos direitos -compreensão que deve levar em conta os aspectos econômicos, sem desprezar, porém, os elementos morais, sociais e históricos da realidade fática- maximiza os resultados da análise jurídica, no sentido de identificar o real fundamento dos direitos fundamentais, bem como os instrumentos jurídicos e econômico adequados para sua efetivação.

O presente trabalho justifica-se, em primeiro lugar, pela insuficiência de pesquisas, trabalhos científicos e bibliografia específica sobre o assunto, o que torna fundamental uma abordagem panorâmica que discorra sobre o universo das relações que envolvem os custos dos direitos e seus corolários. Em segundo lugar, os poucos trabalhos que existem sobre a temática pautam-se em apresentar os custos dos direitos como instrumento jurídico para restringir/limitar os direitos fundamentais sociais, notadamente por se apegarem a apenas um dos vários aspectos da teoria, vinculando-se a uma orientaçãoideológica.

Além disso, no plano fático, estudos ${ }^{3}$ demonstram que os patamares de desigualdade de renda no Brasil permanecem praticamente estáveis após a Constituição Federal de 1988 (PNUD, 2010). São inegáveis os avanços, nos últimos anos, na luta contra a miséria absoluta. Tem havido políticas públicas pontuais visando a redução da pobreza por meio de transferência de renda a famílias carentes, como o Bolsa-Família, ou visando à redução do déficit habitacional por políticas de construção de moradias de interesse social.

Contudo, não houve, como não há, nenhuma política pública visando a alguma reforma estrutural na sociedade. Não existe nenhuma ação ou programa de Estado que promova qualquer alteração do quadro social de desigualdade sistêmica. Ou seja, como a estrutura de desigualdade se mantém, não se realiza qualquer ação contra as causas da pobreza, mas apenas contra seus efeitos. Efeitos que, sem dúvida, devem ser combatidos, pois se trata da vida e da dignidade de pessoas que, sem tais políticas públicas, permaneceriam em situação de terrível vulnerabilidade. Mas pela falta de ataque às causas, no longo prazo, o custo de atuar apenas nos efeitos terá sido muito maior do que se as causas fossem efetivamente combatidas.

Nesse sentido, em todos os indicadores do PNUD 2010 analisados, não se observa a superação de mazelas sociais, bem como não se revela qualquer tendência ao declínio por conta das novas garantias constitucionais. Isso demonstra que a simples retórica constitucional não foi capaz de alterar a estrutura da

\footnotetext{
${ }^{3}$ Relatório de Desenvolvimento Humano 2010. A Verdadeira Riqueza das Nações: Vias para o Desenvolvimento Humano. O Índice de Desenvolvimento Humano (IDH) permanece, aqui, como uma medida de verificação do bem-estar social baseada em três dimensões: saúde, educação e renda. Neste Relatório, porém, foram introduzidas três novas medidas na família de índices do IDH: o Índice de Desenvolvimento Humano Ajustado à Desigualdade, o Índice de Desigualdade de Gênero e o Índice de Pobreza Multidimensional. Estas medidas inovadoras incorporam avanços recentes na teoria e na medição e suportam a nuclearidade da desigualdade e da pobreza no quadro do desenvolvimento humano.
} 
realidade social, nem as supostas promessas foram capazes de melhorar a vida das pessoas de modo universal, no âmbito de sua reprodução social e da dinâmica das relações cotidianas.

Em que pese a falta de políticas públicas que atuem nas causas da pobreza -ou, em termos jurídicos, nas causas da falta de efetividade de direitos sociais-, políticas de inclusão social para resgate de grupos sociais vulneráveis, a serem necessariamente conduzidas por instituições governamentais democráticas, devem ser efetivadas sob a ótica da eficiência econômica, pois em um ambiente de escassez de recursos e necessidades humanas ilimitadas, deve-se prezar pela adequada administração e alocação dos recursos disponíveis. E isso só é possível por meio da compreensão que os direitos fundamentais determinam, como finalidade valorativa, a tomada de decisões economicamente eficientes. Assim, antes de ser um mero artifício ideológico para denegação de direitos, a compreensão da escassez de recursos, ao lado da correta compreensão dos custos dos direitos, a partir da análise de custo-benefício, significa um meio de converter o sistema jurídico em um poderoso instrumento de transformação social, representando também uma justificativa para o próprioDireito.

Nesse sentido, o trabalho divide-se em duas partes principais, a primeira pautada na exposição, descrição e estabelecimento de conceitos e terminologias jurídicas que serão necessários para compreensão da segunda parte, voltada para a discussão dos custos dos direitos e sua real importância para maximização e efetivação dos direitos fundamentais.

Destarte, em um primeiro momento, trataremos da categorização dos direitos fundamentais como direitos objetivos e/ou subjetivos para, em seguida, pontuarmos a diferença entre direitos fundamentais de primeira dimensão (ou negativos) e de segunda dimensão (ou positivos), em especial a partir dos conceitos historicamente afirmados e construídos no embate entre os defensores do Estado liberal e os defensores do Estado de Bem-Estar Social, destacando a diferenciação de tutela dos direitos de primeira dimensão e dos de segunda dimensão.

Em um segundo momento, propomos compreender a teoria dos custos dos direitos não como mera objeção à concretização dos direitos fundamentais prestacionais, mas no sentido de demonstrar e superar a falsa dicotomia entre direitos fundamentais positivos/negativos, reconhecendo que todos os direitos fundamentais são positivos -isto é, todos têm custos-e, portanto demandam algum tipo de prestação pública para sua efetivação, sendo afetados pela ausência de recursos e, por consequência, constituem-se em frutos de uma opção políticosocial. Por fim, reservamos um espaço para discutir dois conceitos de suma importância no âmbito da teoria dos custos dos direitos: a reserva do possível e o mínimoexistencial.

A construção desse novo modo de encarar a teoria dos custos dos direitos, desenvolvida nesse trabalho, permite que prestações públicas de cunho eminentemente social, materializadas, em regra, em políticas públicas 
efetivamente (re)distributivas, sejam adequadamente refletidas e corretamente implementadas, otimizando as escolhas públicas em um cenário de escassez de recursos.

Além disso, demonstra claramente o aspecto político-ideológico na decidibilidade de colisão de normas jurídicas, que representam na verdade colisão de interesses bem definidos, sendo a resolução realizada por meio de opção política que envolve o sacrifício integral ou parcial de um dos direitos invocados, ${ }^{4}$ sendo, portanto, decisões trágicas, principalmente por dois aspectos: primeiro, porque decidir investir os recursos existentes em determinada área significa, ao mesmo tempo, deixar de atender outras necessidades; segundo, que as opções políticas assumidas não são -ou raramente são- escolhas motivadas por um anseio social geral, refletindo, antes disso, os interesses dos grupos que estão no poder.

\section{DIREITOS FUNDAMENTAIS COMO DIREITOS OBJETIVOS E SUBJETIVOS}

No estudo dos direitos fundamentais, o primeiro óbice que se apresenta é a própria delimitação do objeto de estudo pois, se existem direitos fundamentais, é certo que existem direitos não-fundamentais. A grande dificuldade está em identificar o elemento diferenciador desses dois grupos de direitos. Nesse sentido, duas acepções são dominantes entre os juristas para estabelecer essa distinção.

A primeira adota um critério formal, levando em consideração a posição topográfica que esses direitos ostentam na Constituição Federal, bem como nos tratados internacionais. Ressalta-se que, nessa acepção, os direitos só aparecem como fundamentais depois que as autoridades às quais se atribui o poder político legislativo tenham reconhecido sua positividade. ${ }^{5}$ Deste modo, entende-se que existem e devem existir direitos humanos, anteriores e fora do direito positivo, ${ }^{6}$ mas não haveria direitos fundamentais senão a partir da sua incorporação pelo ordenamento jurídico.

\footnotetext{
${ }^{4}$ A este respeito, cf. MASTRODI (2014).

${ }_{5}^{5}$ Em estudo realizado por Andrei KOERNER (2002), os trabalhos internacionais no debate sobre direitos humanos foram abordados a partir de dois eixos: de ordem política (prevalência da ordem global ou da estatal) e de concepção do Direito (institucional ou sociológica); logrando organizar a exposição de quatro tipos empíricos ou posições polares, decorrentes da combinação simples dos eixos de análise, quais sejam: globalistas (global, institucional), "estatalistas" (estatal, institucional), contextualistas (estatal, sociológico) e translocalistas (global e sociológico). Em estudo posterior, esse autor se aprofundou na exposição da perspectiva "estatalista" que considera ser, ainda hoje, a principal abordagem sobre os direitos humanos no campo das disciplinas jurídicas, afirmando que: "A perspectiva estatalista considera justificada a pretensão de validade universal dos direitos humanos, desde que seus enunciados sejam tomados como parâmetros morais para a convivência dos agentes nas relações internacionais. Do ponto de vista interno, os direitos humanos são traduzidos nos direitos fundamentais da Constituição e na estruturainstitucionaldo Estado de Direito" (KOERNER, 2003, p. 146, grifo nosso).

${ }^{6}$ COMPARATO (2010) expõe os fundamentos intelectuais, que são construídos histórica e sucessivamente no campo da religião, da filosofia e da ciência para a compreensão da pessoa humana e para afirmação da existência de direitos humanos, universais e inerentes a todos e cada um. Em sentido contrário, SANTOS (1997) defende uma desconstrução da concepção universalista dos direitos humanos em prol de uma concepção multicultural, no sentido de reforçar o reconhecimento do potencial progressista e emancipatório dos direitos humanos.
} 
No entanto, cabe ressaltar que, ainda que se possa estabelecer um catálogo positivado de direitos fundamentais, não é possível determinar a quantidade e a qualidade dos bens necessários para satisfazer esses direitos, pois seu conteúdo apresenta a dinâmica e o ritmo de expansão da riqueza material e cultural da sociedade (HIERRO, 2000, p.370-371).

A segunda acepção vincula-se a um critério material, no sentido de identificar como fundamentais aqueles direitos que tutelam os valores mais elevados da sociedade em um determinado tempo, e que reconhecem e garantem a qualidade de pessoa ao ser humano, ainda que não reconhecidos no ordenamento estatal, atribuindo um caráter ético aos direitos fundamentais, no sentido de que a dignidade da condição humana exige o respeito a certos bens e valores em qualquer circunstância, pois são condições necessárias para o desenvolvimento integral da personalidade humana (HIERRO,2000).

Porém, tal acepção caracteriza-se pelo excesso de conceitos jurídicos indeterminados e pela insuficiência de parâmetros objetivos para operacionalização desses direitos, além de não impedir que certos privilégios da minoria dominante, sob a máscara ideológica de direitos fundamentais, sejam consagrados como valores elevados da pessoa humana, promovendo assim uma legitimação da dominação. Nesse sentido, Mastrodi (2012, p. 175177):

[...] A trama ideológica retroalimenta a compreensão da estrutura social, dando relevância a certos valores e princípios (extraídos das relações sociais) como se esses valores e princípios fossem, eles próprios, os determinantes da estrutura social [...] A universalização de uma visão de mundo e o estabelecimento de certos valores abstratos são fatores de consenso desenvolvidos em termos ideológicos. Ao se apelar para símbolos e conceitos abstratos com os quais os dominados podem concordar consigna-se legitimidade às práticas sociais.

Assim, no âmbito desse trabalho, consideramos mais adequado adotar uma acepção dos direitos fundamentais que abarque o critério formal ao mesmo tempo em que compreenda o critério material em uma perspectiva realista. Consideramos direitos fundamentais, portanto, o catálogo positivado de direitos humanos em certa ordem jurídica, reconhecendo que a incorporação desses direitos ao ordenamento ocorreu em razão da construção intelectual e valorativa, consubstanciado em um processo histórico-dialético de correlação de forças dos grupos sociais de determinada sociedade. Na mesma esteira e em uma abordagem mais detalhada, Mastrodi (2012) afirma:

Entendemos que não é adequado compreender os direitos fundamentais apenas em seu aspecto jurídico-normativo (forma de direito positivo) ou em sua dimensão valorativa (conteúdo de justiça) pois, se negarmos a processualidade histórica que os desenvolveu e consolidou, se deixarmos de lado as relações sociais de dominação sobre as quais eles foram gerados, ficarão ocultos os fatores reais de poder da sociedade, i.e., os motivos materiais que, em última instância, condicionam a conformação histórica das forças sociais e a organização de sociedade nos termos dessa mesma conformação.

Essa primeira concepção dos direitos fundamentais, considerado como direito objetivo, segue na esteira das lições de Paulo BONAVIDES (2010), que discorre que os direitos fundamentais em sua perspectiva objetiva formam uma pauta de valores de natureza jurídico-objetiva, acolhida pela sociedade e que serve como diretrizpara _vol.09, nº. 02, Rio de Janeiro, 2016. pp. 695-722 
a aplicação e interpretação do direito infraconstitucional. Tal efeito é comumente chamado de eficácia irradiante dos direitos fundamentais, porque os valores dos direitos fundamentais refletem por todo o ordenamento jurídico, funcionando como critério de interpretação deste, apontando o sentido e alcance das demais normas jurídicas.

Ainda em relação à caracterização dos direitos fundamentais como direito objetivo, torna-se relevante verificar com qual espécie de norma que tais direitos se identificam e, para esse fim, podemos levar em conta numerosas distinções teórico-estruturais. Porém, para a teoria dos direitos fundamentais, principalmente após a obra de Robert ALEXY, a mais importante é a distinção entre regras e princípios. Ela constitui a base para a solução dos problemas centrais da dogmática dos direitos fundamentais. Sem ela, não pode existir uma teoria satisfatória da colisão, bem como uma teoria suficiente acerca do papel que desempenham os direitos fundamentais no sistema jurídico?

As regras são normas jurídicas vinculativas com conteúdo apenas funcional, que impõem, permitem ou proíbem uma conduta; apresentam grau de abstração amplo, embora mais reduzido que o dos princípios, o que possibilitaria uma aplicação direta e imediata, de modo que o conflito entre regras (antinomia) seria solucionado no plano da validade (all or nothing) por meio dos critérios clássicos, cronológico, hierárquico e de especialidade. Em outras palavras, ocorre conflito entre regras quando nova regra tratar do mesmo assunto de forma integral e diversa (critério de exclusão de ordem cronológica), ou se outra regra de hierarquia superior dispuser de forma diversa sobre o mesmo assunto (critério de exclusão de ordem hierárquica), ou, ainda, se sobrevier legislação especial passando a tratar a matéria de forma mais específica (critério de exclusão levando em conta a especialidade da matéria tratada) (BOBBIO, 1995).

A segunda espécie de norma, os princípios, caracteriza-se por estabelecer fins (determinado estado de coisas) a serem atingidos pelos respectivos destinatários sem especificar com precisão os comportamentos (os meios) a serem observados. Por essa razão, apresentam um grau de abstração mais elevado que o das regras, por expressarem valores. Estabelecem no ordenamento jurídico ao menos três funções, quais sejam, a interpretativa (hermenêutica), a integrativa (suplementar) e a regulamentadora. No que tange à colisão de princípios, por estes serem considerados "mandados de otimização", resolve-se no plano da efetividade por meio da ponderação dos valores envolvidos, avaliando a "correlação entre o estado de coisas a ser promovido e os efeitos decorrentes da conduta havida como necessária à sua promoção" (ÁVILA, 2012, p.85. MASTRODI, 2014, p. 578-580).

Percebe-se que a definição de princípios e regras é pautada em diversos critérios (fundamentabilidade, generalidade, abstração, hierarquia, dentre outros), o que acaba por delinear as características das duas espécies normativas. Com base em tais características e apesar de posicionamentos em contrário, identificamos os direitos fundamentais como princípios, notadamente por prescreverem "mandamentos de otimização", podendo o

\footnotetext{
${ }^{7}$ Nesse sentido, inolvidável são as lições de ÁVILA (2012) que, recorrendo a teses de Ronald Dworkin e Robert Alexy, busca estabelecer a melhor definição de regras eprincípios.
} 
preceito ser cumprido em diversos graus de intensidade, na maior medida possível, de acordo com as possibilidades fáticas e jurídicas existentes no caso concreto (BORGES, 2010). Ademais, restringindo-se ao tema abordado, considerar os direitos fundamentais como regras seria inócuo, isso porque, independentemente de seus limites imanentes, a restrição a um direito fundamental, pela via de uma lei orçamentária, não seria uma restrição, posto que isto (restrição) não é algo teoricamente possível para essa espécie normativa (CHAVES, 2008).

Expostos esses entendimentos, que, contudo, não são pacíficos, consideramos, sob o aspecto da normatividade, que os direitos fundamentais são princípios e, mais do que isso, são princípios materiais, pois expressam conteúdo jurídico autônomo (aproximando-se, nesse aspecto, das regras jurídicas), promovendo a criação de situações jurídicas subjetivas (direito, dever, poder, sujeição, faculdade, ônus etc...). Diferem, assim, dos princípios operacionais (formais), que se constituem em mera estrutura de aplicação das outras normas (regras ou princípios). ${ }^{8}$ Assim, sem embargo de reconhecer que os direitos fundamentais são normas na modalidade de princípios jurídicos materiais, o ponto nevrálgico se refere à caracterização dos direitos fundamentais como direitos subjetivos.

Nesse ponto, é necessário pontuar que existem diversas teorias ${ }^{9}$ acerca da natureza jurídica e do conceito de direito subjetivo. No entanto, para o âmbito desse trabalho, seguimos as lições de Ingo Wolfgang SARLET (2003) e Paulo BONAVIDES (2010), que compreendem que os direitos subjetivos conferem a possibilidade ao seu titular da defesa e exigibilidade judicial dos respectivos direitos, requisitando do destinatário da norma a contraprestação de um deverjurídico.

Não obstante críticas e múltiplas tentativas de desenvolvimento de conceitos correlatos, o direito subjetivo manteve-se como categoria fundamental, pois tal instituto jurídico assumiu um conteúdo em cada momento histórico, que o tornou mais útil às finalidades eleitas, segundo as valorações então vigentes. Nesse sentido, a construção do conceito de direito subjetivo é marcadamente privatista, pois se desenvolveu sob a ótica liberal/formal/burguesa de direito-dever, baseada no individualismo e na autonomia privada e vinculado à noção de propriedade e ao modelo de Estado liberal (GALDINO, 2005,p.143-146).

\footnotetext{
${ }^{8}$ Embora não haja maiores implicações para o desenvolvimento do tema, destacam-se, ilustrativamente, as colocações de ÁVILA (2012, p. 143) sobre postulados, quando os define como "normas imediatamente metódicas que instituem os critérios de aplicação de outras normas [princípios e regras] situadas no plano objeto da aplicação”. Nesse aspecto, podem ser considerados princípios formais ou operacionais, pois dependem da conjugação de razões substancias para sua aplicação.

${ }^{9}$ Por uma questão de espaço, não será detalhadamente trabalhada, aqui, a perspectiva subjetiva dos direitos fundamentais. Para evitar que a omissão seja muito significativa, mencionam-se as principais teorias acerca da natureza jurídica e do conceito de direito subjetivo, a saber: a) teoria da vontade (de Savigny e Windscheid), pela qual se entende que o direito subjetivo é o poder da vontade reconhecido pela ordem jurídica. Dessa forma, ainda que os titulares não possuam vontade ou não possam expressá-la, os direitos subjetivos subsistiriam, já que a vontade não é do indivíduo, mas do próprio ordenamento jurídico; b) teoria do interesse (de Ihering), para a qual o direito subjetivo seria o interesse juridicamente protegido por meio de uma ação judicial; c) teoria Mista (de Jellinek, Saleilles e Michoud), pela qual se define que o direito subjetivo seria composto por ambos os elementos, o interesse juridicamente protegido (elemento objetivo) e o poder da vontade reconhecido pela ordem jurídica (elemento subjetivo). A este respeito, cf., por todos, GALDINO (2005).
} 
Porém, essas formulações conceituais acerca dos direitos subjetivos, consolidadas no seio da então nascente e hoje dominante Teoria Geral do Direito (em que o direito privado é entendido como direito geral), revelaram-se manifesta e absolutamente inadequadas para se designarem as situações subjetivas referentes a direitos humanos ou mesmo outras situações jurídicas de direito público, bem como para lhes assegurar a respectiva tutela, pois despreza muitas notas marcantes da natureza pública dos direitos reconhecidos em face do Estado.

Nesse sentido, assume relevo a construção teórica do norte-americano Wesley Neocomb HOHFELD, exposta por Flávio GALDINO (2005, p. 136-142) em sua obra Introdução à teoria dos custos dos direitos: direitos não nascem em árvores. De acordo com essa importante construção, a redução das relações jurídicas suscitadas em torno dos direitos subjetivos em simples termos de direito-dever não expressa as várias posições que os sujeitos ocupam nas suas múltiplas relações e situações. Assim, HOHFELD identifica os sentidos fundamentais que essas expressões (direito e dever) possuem na linguagem jurídica, revelando que ao conteúdo do conceito de direito subjetivo pode-se atribuir pelo menos quatro tipos de significações, ou seja, operações jurídicas que são realizadas por referência a ele, a saber: pretensão, faculdade, potestade eimunidade. ${ }^{10}$

Dessa forma, os direitos fundamentais, caracterizam-se como situações jurídicas (pretensão, direito, faculdade, potestade e imunidade) de direito fundamental, que se expressam como direitos públicos subjetivos, ${ }^{11}$ pois são dotados de exigibilidade em face do Estado, o que representa para o indivíduo a possibilidade de acesso ao aparato estatal do Poder Judiciário para a tutela do seu respectivo interesse, bem ou necessidade, ou seja, o Estado possui deveres no sentido de promover a satisfação de direitos fundamentais, entendidos como direitos subjetivos dos indivíduos (DUARTE, 2004, p. 113).

Apesar do grande avanço em compreender os direitos fundamentais como direitos subjetivos -ou melhor, como direitos públicos subjetivos-, representando situações valoradas positivamente pelo ordenamento, que podem assumir outras formas que não se confundem com o rígido esquema direito(pretensão)-dever, o grande problema hodierno não é mais a fundamentação ou o reconhecimento da exigibilidade individual dos direitos fundamentais -em especial dos direitos fundamentais sociais-, mas sim a exigibilidade de caráter coletivo de tais direitos, voltada ao cumprimento, por meio de políticas públicas, dos "objetivos e programas de ação governamentais constitucionalmente delineados" (DUARTE, 2004,p.114).

\footnotetext{
${ }^{10}$ Algo, aliás, também identificado no início do século XX por Hans KELSEN (2003, p.140-145), autor cuja obra fundamenta outras pesquisas sobre o tema, como em Mastrodi (2014, p. 580).

${ }^{11}$ Cabe destacar que a grande inovação desta figura [direito subjetivo público], na época de seu surgimento na Alemanha no final do século XIX, foi o reconhecimento de um poder de exigência (pretensão) do particular em face dos Poderes Públicos, tendo como objeto a prestação devida, que se traduzia em um comportamento positivo (prestação material) ou omissivo (nãointervenção na esfera de liberdade individual). O direito público subjetivo configura-se, assim, como um instrumento jurídico de controle da atuação do poder estatal, pois a partir do desenvolvimento deste conceito, passou-se a reconhecer situações jurídicas em que o Poder Público tem o dever de dar, fazer ou não fazer algo em proveito de um particular, permitindo ao seu titular constranger judicialmente o Estado a efetuar sua obrigação (DUARTE, 2004, p.113).
} 
No contexto de um Estado social e democrático de Direito, que incorporou em seu catálogo de direitos fundamentais um extenso rol de direitos sociais, a figura do direito público subjetivo deve ser interpretada de forma ampliada em relação ao momento de seu surgimento, originariamente vinculado à estrutura do Estado Liberal e voltada para proteger valores marcadamente individualistas (propriedade privada e autonomia da vontade), para também assegurar a exigibilidade coletiva e não apenas individual, do bem jurídico protegido. Em outras palavras, o controle da atuação do Estado não mais está adstrito à exigibilidade de uma conduta negativa, no sentido de não invadir a esfera de liberdade do indivíduo (senão quando expressamente autorizado em lei), ou de uma conduta positiva que concretize direitos sociais de um único indivíduo ou grupo de indivíduos; mas deve estar voltado ao "cumprimento [por meio de políticas públicas] dos objetivos e programas de ação governamentais constitucionalmente delineados", como os direitos sociais à educação, à saúde, à moradia, ao trabalho, dentre outros previstos no artigo 6º da Constituição Federal de 1988 (DUARTE, 2004, p.114).

Em resumo, os direitos fundamentais, como demonstrado acima, podem ser compreendidos como direitos objetivos ao serem identificados como normas na modalidade de princípios jurídicos materiais, ao mesmo tempo que se expressam como direitos públicos subjetivos, que se traduzem em diversas situações jurídicas subjetivas (pretensão, direito, faculdade, potestade e imunidade) de direitos fundamentais, conferindo perante o Estado, além da exigibilidade individual, a exigibilidade coletiva dos bens e interesses tutelados por tais direitos. Verifica-se, portanto, que as noções de direito objetivo e direito subjetivo assumem algumas peculiaridades quando aplicadas aos direitos fundamentais, pois compreendidas de modo complementar e interrelacionado.

\section{DIREITOS SOCIAIS COMO DIREITOS FUNDAMENTAIS SUBJETIVOS}

As considerações expostas acima assumem particular relevância no que tange aos direitos fundamentais sociais, pois uma das formas mais comuns de negar sua efetividade é furtar-lhes a característica de direitos fundamentais em seu duplo aspecto, objetivo e subjetivo. ${ }^{12}$ Afastados da condição de direitos fundamentais, assim, ficam privados da aplicabilidade imediata e excluídos da garantia constitucional de cláusulas pétreas. Além disso, os princípios materiais (normas) que expressam direitos sociais ora são entendidos como meios subsidiários de interpretação e integração da norma, ${ }^{13}$ ora como normas de eficácia limitada ou, ainda, como meras pautas

\footnotetext{
${ }^{12}$ Nesse trabalho, grosso modo, os direitos fundamentais, no aspecto objetivo, são considerados como normas válidas e eficazes na modalidade de princípios jurídicos materiais. Em seu aspecto subjetivo, os direitos fundamentais são identificados como direitos públicos subjetivos, que conferem ao titular a possibilidade de defesa e exigibilidade judicial dos respectivos direitos, requisitando a contraprestação do destinatário da norma. Ver tópico 1: Direitos Fundamentais como Direitos Objetivos e Subjetivos.

${ }^{13}$ Cf. art. 4o da Lei de Introdução às Normas do Direito Brasileiro. Refere-se ao Decreto-Lei no 4657, de 4 de setembro de 1942, originariamente denominado LICC - Lei de Introdução ao Código Civil. Seu artigo $4^{\circ}$ dispõe que "quando a lei for omissa, o juiz decidirá o caso de acordo com a analogia, os costumes e os princípios gerais de direito".
} 
programáticas, ${ }^{14}$ sendo submetidos à limitação da reserva do possível, tanto jurídica como econômica, ${ }^{15}$ ou restritos à objetivação de um mínimo existencial. ${ }^{16}$

Não obstante, as teorias dos direitos fundamentais, em seu desenvolvimento, têm contemplado os direitos sociais, e estes têm sido considerados como normas jurídicas válidas e de eficácia imediata. O constituinte, ao definir os valores supremos do Estado (Social) Democrático de Direito, considerou os direitos sociais como categoria essencial ao regime que pretenderam estabelecer por meio da Constituição e, portanto, pertencentes à mesma categoria hierárquica dos direitos civis e políticos (BARRETO, 2003). A Constituição Federal em art. $3^{\circ}$ definiu como objetivos fundamentais da República Federativa do Brasil: "erradicar a pobreza e a marginalização e reduzir as desigualdades sociais e regionais", bem como "promover o bem de todos, sem preconceitos de origem, raça, sexo, cor, idade e quaisquer outras formas de discriminação". Além disso, ao dispor no artigo 6o dentro do Título II, Dos Direitos e Garantias Fundamentais, que: "são direitos sociais a educação, a saúde, o trabalho, a moradia, o lazer, a segurança, a previdência social, a proteção à maternidade e à infância, a assistência aos desamparados, na forma desta Constituição", expressamente considerou os direitos sociais como direitos fundamentais.

Apesar de considerar que o cerne da questão sobre os direitos fundamentais sociais, hoje, não é tanto justificá-los, mas sim protegê-los, ${ }^{17}$ no sentido de buscar sua efetivação, há determinados momentos em que a justificação e fundamentação dos direitos é etapa imprescindível e indissociável da sua proteção. Porém, nunca se pode perder de vista que os direitos fundamentais não são apenas conceitos aleatórios e abstratos, mas expressam interesses reais de determinado grupo social.

Assim, a proteção de que gozam, na atualidade, os direitos de primeira dimensão, ${ }^{18}$ é resultado de todo um enredado processo histórico de lutas sociais pela preservação de interesses e necessidades, que aprofundaram a importância da temática dos direitos humanos para a construção do Estado liberal de Direito. A tradição liberal, entretanto, estabeleceu a questão dos direitos humanos em função exclusivamente da propriedade privada, que

\footnotetext{
${ }^{14}$ Sobre a classificação das normas constitucionais em eficácia plena, contida e limitada ou reduzida, bem como o conceito de norma programática (SILVA, 2009).

${ }^{15} \mathrm{~A}$ reserva do possível jurídica diz respeito à necessidade de integração legal, por meio de uma lei infraconstitucional, para que os direitos sociais operem a plenitude de seus efeitos. A reserva do possível econômica, decorrência direta da teoria dos custos dos direitos, serve, comumente, de justificativa para que o Estado deixe de cumprir o seu papel na efetivação de vários direitos, situação que se torna consideravelmente crítica quando se tratam de direitos fundamentais sociais. Ver tópico 5: Custos dos Direitos: Reserva do Possível versus Mínimo Existencial.

${ }^{16}$ No que tange à redução dos Direitos Sociais ao Mínimo Existencial, esclarecedora é a obra de TORRES (2003), A metamorfose dos Direitos Sociais em Mínimo Existencial. O autor, em tal texto, menciona duas dimensões para o mínimo existencial, ressaltando que ambas se relacionam intimamente com a liberdade. A primeira dessas dimensões, negativa, impossibilita a atuação do Estado, no sentido de tributação, no que tange à situação econômica do cidadão. A outra, positiva, refere-se às prestações estatais materiais que visam à preservação da liberdade; defende, assim, um núcleo mínimo fundamental dos direitos sociais.

${ }^{17}$ Trata-se da consagrada frase de BOBBIO (1992, p.24) "O problema fundamental em relação aos direitos do homem, hoje, não é tanto o de justificá-los, mas o de protegê-los. Trata-se de um problema não filosófico, mas político”.

${ }^{18}$ Ver tópico 3 deste artigo: As Dimensões (Gerações) dos Direitos Fundamentais e a Classificação em Direitos Positivos e Negativos.
} 
iria sedimentar, proteger e assegurar o produto do exercício da autonomia, da liberdade e do trabalho. Essa a razão pela qual os sistemas políticos e jurídicos do Estado liberal organizaram-se em função e para garantia do exercício das liberdades e igualdades de uma sociedade de proprietários (BARRETO, 2003), e não de cidadãos ou de seres humanos.

A este respeito, cabe comentar a obra de COMPARATO (2010, p. 63-64), em que o autor expõe que a democracia moderna, na verdade, foi uma construção política e institucional engendrada pela burguesia para extinguir os antigos privilégios dos dois principais estamentos do antigo regime -o clero e a nobreza- e tornar o governo responsável perante a classe burguesa. Portanto, o espírito original da democracia moderna não foi a defesa do povo pobre contra a minoria abastada, mas sim a defesa dos novos proprietários ricos contra um regime de privilégios estamentais e de um governo irresponsável que contrariava os interesses do grupo social então ascendente. Foi para atender a estes interesses que foram construídos, desenvolvidos e consagrados os principais institutos da democracia liberal, a saber: os direitos individuais, notadamente a proteção à propriedade privada e autonomia da vontade, que se traduzem na limitação vertical do Estado, e a separação dos poderes políticos, que proporciona a limitação horizontal do Estado em razão do exercício, em órgãos distintos, das funções legislativa, executiva e judiciária.

A transformação do Estado liberal em direção ao Estado social e democrático de Direito justifica-se pela presença dos direitos fundamentais sociais (SARLET, 2001, p.18)' resultado de um processo histórico-dialético que se radica na Revolução Industrial, com o surgimento da "questão social" em razão do processo de superexploração da mão-de-obra cumulado com a inexistência de leis que amparassem o trabalhador; avança um pouco com a Constituição Francesa de 1793 que, apesar de cunho liberal e individualista, já apresentava indícios de direitos de caráter social. Porém, o aprofundamento dos direitos sociais só ocorre com o movimento socialista, iniciado na primeira metade do século XIX, ${ }^{19}$ atingindo sua expressão máxima no século XX, com o Estado do Bem-Estar, o constitucionalismo social (Constituição Mexicana de 1917 e a Constituição Alemã de 1919) e o reconhecimento internacional expresso dos direitos sociais como direitos humanos (fundamentais) em dois principais instrumentos: a Declaração Universal dos Direitos Humanos de 1948 e, posteriormente, o Pacto Internacional sobre Direitos Econômicos, Sociais e Culturais de 1966 (COMPARATO,2010).

O titular dos direitos fundamentais sociais, com efeito, não é o ser humano abstrato, é o conjunto dos grupos sociais esmagados pela miséria, a fome e a marginalização. Considerando que essas mazelas sociais não são calamidades da natureza nem "efeitos necessários da organização racional das atividades econômicas," (COMPARATO, 2010, p. 66) os direitos sociais passaram a ser entendidos como núcleo normativo central do

\footnotetext{
${ }^{19}$ Assim é que, conforme COMPARATO (2010, p.351), os direitos sociais surgiram, historicamente, "como criações do movimento socialista, que sempre colocou no pináculo da hierarquia de valores a igualdade de todos os grupos ou classes sociais, no acesso a condições de vida digna".
} _vol.09, nº. 02, Rio de Janeiro, 2016. pp. 695-722 
Estado social e democrático de direito, na medida em que pretendem fornecer os recursos fáticos para uma efetiva fruição das liberdades, que apenas podem ser alcançadas pela compensação da desigualdade social e econômica da sociedade liberal (SARLET, 2001, p. 18). Assim, em vez de serem direitos contra o Estado, constituem-se em direitos por meio do Estado, exigindo do Poder Público certas prestações materiais (SALDANHA, 2009).

Nesse sentido, além do caráter fundamental dos direitos sociais, eles se expressam como verdadeiros direitos públicos subjetivos. No contexto de um Estado Social de Direito, conforme entendimento já exposto, a figura do direito público subjetivo, quando aplicada a um direito fundamental e, em especial, a um direito fundamental social, deve ser interpretada de forma ampliada a fim de assegurar a exigibilidade coletiva, e não apenas individual, do bem jurídico protegido. Nota-se que não se quer negar a proteção individual dos direitos sociais, mas a dimensão social de tais direitos somente se realiza por meio de políticas públicas, o que envolve interesses que transcendem a esfera do indivíduo singularmente considerado (DUARTE, 2004, p.117).

$\mathrm{Na}$ cultura jurídica brasileira, fortemente marcada por valores inerentes ao Estado liberal de Direito, a utilização de uma categoria consagrada pela tradição liberal/formal/burguesa, como a do direito subjetivo, para a tutela de um direito social contribui para a superação de certos preconceitos, notadamente aquele relativo ao reconhecimento da "exigibilidade coativa e imediata" perante o Poder Judiciário desta categoria de direitos (DUARTE, 2004, p.117). Sendo assim, é puramente ideológico, e não científica, a suposição de que normas que tratam de direitos sociais necessitariam de ulteriores especificações para possibilitar sua concretização, bem como embasar oposição a atos (legislativos, administrativos e judiciais) descompassados com tal mandamento (MELLO, 2009, p. 37).

Assim, a Constituição Federal, quando dispõe sobre a realização, por meio dos direitos sociais, da Justiça Social -mesmos nas normas chamadas programáticas- está, na verdade, imperativamente constituindo o Estado Brasileiro no indeclinável dever jurídico de realizá-la. Nesse sentido, Celso Antonio Bandeira de MELLO (2009, p.36 e 52), ao construir um novo modelo de classificação das normas constitucionais, tomando como critério a consistência e a amplitude dos direitos imediatamente resultantes para o indivíduo, disserta que: "é irrecusável o direito dos cidadãos de postular jurisdicionalmente os direitos que decorrem das normas constitucionais reguladoras da Justiça Social", pois estão entre as normas que encerram bens e interesses que são frutos expressivos da cultura e história de um povo, não sendo, portanto, meras exortações ou conselhos que se traduzem em embelezamentos estratégicos e legitimadores da ordem normativa estatal mas, ao contrário, estabelecem comportamentos obrigatórios para o Estado e para os indivíduos.

Dessa forma, depreende-se dessas disposições constitucionais: a) ou a garantia do exercício de poderes; b) ou a satisfação de uma utilidade concreta a ser satisfeita pela prestação de outrem; c) ou, ao menos, a vedação de comportamentos discrepantes dos vetores constitucionais (MELLO, 2009, p.22-26). 
Apesar da caracterização dos direitos sociais como direitos fundamentais subjetivos que, em tese, eliminaria qualquer embargo teórico-jurídico para realização de tais direitos, a construção do princípio da reserva econômica do possível apresenta-se como o principal óbice no que se refere aos direitos sociais, já que sustenta que a efetividade de tais direitos depende de disponibilidade orçamentária, em razão de se exigirem prestações materiais por parte do Estado, o que demanda alto custo em face de um ambiente de escassez de bens e recursos.

Porém, não obstante essa perspectiva clássica em que os custos dos direitos assumem uma função meramente limitativa (negativa), pretende-se demonstrar, a seguir, a superação desse modelo por meio do rompimento da tradicional tipologia positivo/negativo dos direitos fundamentais.

\section{AS DIMENSÕES (GERAÇÕES) DOS DIREITOS FUNDAMENTAIS E A CLASSIFICAÇÃO EM DIREITOS POSITIVOS ENEGATIVOS}

Com o desenvolvimento intelectual da teoria dos direitos fundamentais, diversas classificações de tais direitos foram elaboradas adotando distintos critérios, porém, no âmbito da teoria dos custos dos direitos, duas delas apresentam peculiar relevância para a discussão do tema: a classificação em dimensões (gerações) que, aparentemente, adota o critério da evolução histórica dos direitos fundamentais, e a classificação em direitos positivos e negativos, que adota como critério a espécie de obrigação que o Estado deve prestar. Cabe, dessa forma, discorrer, ainda que brevemente, sobre as mencionadas classificações.

A teoria das gerações dos direitos humanos, que no âmbito do ordenamento jurídico de um Estado são denominados direitos fundamentais, foi proferida pela primeira vez pelo professor e jurista Karel Vasak, em 1979, na aula inaugural do Curso do Instituto Internacional dos Direitos do Homem, em Estrasburgo. Nessa aula, Vasak utilizou a expressão "gerações de direitos do homem", buscando, metaforicamente, apontar para a evolução dos direitos humanos com base no slogan da Revolução Francesa (liberdade, igualdade e fraternidade) (LIMA, 2005, p. 58-59).

De acordo com Vasak, a primeira geração dos direitos humanos remete aos direitos civis e políticos, fundamentados no valor liberdade (liberté), que despontaram no final do século XVII com a Revolução Francesa e as demais revoluções burguesas. A primeira dimensão visa a afastar os privilégios estatais e corporativos do Estado, resguardando a liberdade do indivíduo em face do poder estatal (direitos civis), ao mesmo tempo em que concedia ao cidadão a possibilidade de participar desse poder (direitos políticos). Nessa perspectiva, inclui direitos tais como a vida, a liberdade, a propriedade, a igualdade perante a lei, a igualdade no que tange às garantias processuais e a participação política (CHAVES, 2008, p.6-9).

A segunda geração, por sua vez, seria a dos direitos econômicos, sociais e culturais, baseados no valor igualdade (égalité), em seu sentido material. O aprofundamento desses direitos só ocorre com os movimentos 
trabalhista e socialista, iniciados na primeira metade do século XIX, atingindo sua expressão máxima no século XX, com o Estado do Bem-Estar e o constitucionalismo social (este, formalmente iniciado pelas Constituição Mexicana de 1917 e Constituição Alemã de 1919). Tais direitos traduziram-se na participação direta do Estado para ascensão social do cidadão, face ao reconhecimento de sua função social (CHAVES, 2008, p. 6-9).

No final do século XX, notadamente após a Segunda Guerra Mundial e especialmente após a Declaração Universal dos Direitos Humanos de 1948, desenvolveu-se a compreensão de uma terceira geração de direitos humanos vinculada ao valor fraternidade (fraternité), completando o tríptico francês. ${ }^{20}$ Estes direitos transcenderiam o homem-indivíduo para atingir outros grupos da sociedade e, por essa razão, são denominados direitos difusos, sendo expressões desses direitos: o direito ao meio ambiente sadio, o direito do consumidor, o direito ao desenvolvimento econômico sustentável, o patrimônio comum da humanidade, o direito à paz (LIMA, 2005, p. 58-59).

Apesar da teoria das gerações referir-se inicialmente aos direitos humanos, tal teoria, mutatis mutandis, aplica-se aos direitos fundamentais pois, como já exposto, os direitos fundamentais, grosso modo, são considerados o catálogo positivado de direitos humanos constante do ordenamento jurídico deum Estado.

Não obstante a notoriedade e inegável valor didático da teoria das gerações dos direitos humanos/fundamentais, o vocábulo "geração" tem sofrido várias críticas da doutrina nacional e estrangeira, pois o uso desse termo pode dar a falsa impressão de substituição gradativa de uma geração por outra, o que é inadequado, já que os direitos de liberdade não desaparecem quando surgem os direitos sociais e assim por diante, pois o processo de conquista e afirmação dos direitos fundamentais é cumulativo e complementar. Ademais, o termo "geração" pode sugerir equivocadamente a ideia de sequência e/ou sucessão, isto é, de que o reconhecimento de uma nova geração somente pode ou deve ocorrer quando a geração anterior já estiver madura o suficiente, o que é criticável, uma vez que a luta pela concretização dos direitos fundamentais é paralela e contínua, estando sujeita a avanços e retrocessos históricos; além disso, a concretização de tais direitos pode se expressar de maneiras distintas na realidade social e política de cada Estado, não respeitando necessariamente a sequência liberdade-igualdade-solidariedade (CHAVES, 2008, p. 6-9).

Consideramos, no que tange a este trabalho, que a classificação em comento contribui para a atribuição da baixa carga de normatividade aos direitos econômicos, sociais e culturais, em razão de contribuir para a cristalização do estigma de que esses direitos seriam direitos de segunda categoria (LIMA, 2005, p.59-60).

\footnotetext{
${ }^{20}$ Com o desenvolvimento da teoria dos direitos fundamentais e devido ao acelerado e conturbado avanço da tecnologia, da informática e das ciências, novas "gerações" foram incorporadas à tríade inicial, chegando-se a falar em direitos de quarta, quinta, sexta e até sétima geração. A nova "geração" que mais se destacou, porém, foi a quarta, visualizada pelo professor Paulo Bonavides. Para o grande constitucionalista brasileiro, o direito à democracia (direta), o direito à informação e o direito ao pluralismo comporiam a quarta geração dos direitos fundamentais (BONAVIDES, 2010, p.570-572).
} 
Por tais motivos, preferimos o uso do vocábulo dimensões; primeiro, por considerarmos que os direitos fundamentais são direitos interdependentes e complementares; ${ }^{21}$ e segundo, para indicar que um direito fundamental, doutrinariamente compreendido como de primeira dimensão, não está confinado àquela interpretação inicial que, assim, o caracterizou, já que o mesmo direito fundamental, classificado como direito de primeira dimensão em razão do momento histórico de seu reconhecimento estatal, pode ser enquadrado ou assumir características de outra dimensão, dependendo da análise realizada de seu conteúdo sob a conjuntura atual de evolução da sociedade e dos direitos fundamentais. Nesse sentido, cabe o seguinte raciocínio:

[...] o direito de propriedade era um direito absoluto e de cunho estritamente individual, se visto sob a ótica do Estado Liberal e, assim, entendido deve enquadrar-se como de primeira dimensão. Todavia, com o passar do tempo, o crescimento populacional e a escassez de recursos, o conceito de direito de propriedade evoluiu para a compreensão de função social da propriedade, relativizando o cunho individualista desse direito de modo a possibilitar melhor distribuição de riquezas, impedindo, por exemplo, práticas de especulação imobiliária. E, atualmente, com o advento da terceira dimensão dos direitos fundamentais e o direito ao meio ambiente sadio, fala-se em função ambiental da propriedade (CHAVES, 2008, p. 7).

Outro equívoco que pode decorrer dessa teoria é afirmar a ideia de que os direitos de primeira dimensão seriam sempre direitos negativos (de defesa), não-onerosos, enquanto os direitos de segunda e terceira dimensões seriam, em todos os casos, direitos positivos que exigem prestações materiais e, portando, dispendiosos. A dicotomia entre direitos positivos e negativos, que adquire expressividade com o filósofo político britânico Isaiah Berlin, apresenta peculiar importância para a teoria dos custos dos direitos, principalmente quando se estabelece um paralelo com as dimensões dos direitos humanos (CASARIN, 2008, p.283-295).

De acordo com essa classificação, verifica-se que os direitos fundamentais de defesa (negativos) se dirigem a uma obrigação de abstenção por parte dos poderes públicos, implicando para estes um dever de respeito a determinados bens e interesses da pessoa humana, por meio da omissão de ingerências na autonomia de vontade dos particulares, sendo a intervenção na esfera de liberdade pessoal realizada apenas em determinadas hipóteses e certas condições previstas expressa e estritamente em lei (SARLET, 2001, p. 14). Os direitos fundamentais na sua função defensiva caracterizam-se, portanto, essencialmente, como direitos negativos, dirigidos precipuamente a uma conduta omissiva por parte do Estado. Abrangem os denominados direitos de liberdade, a igualdade perante a lei, o direito à vida e o direito de propriedade, os quais integram, como exposto acima, a primeira dimensão dos direitos humanos.

\footnotetext{
${ }^{21} \mathrm{Na}$ mesma linha, reforçando a característica de indivisibilidade dos direitos humanos/fundamentais, cabe transcrever o artigo $5^{\circ}$ referente à Declaração e o Programa de Ação de Viena, documento solene produzido na Conferência Mundial de Direitos Humanos, realizado em Viena no ano de 1993, que dispõe: “Todos os direitos humanos são universais, indivisíveis, interdependentes e inter-relacionados. A comunidade internacional deve tratar os direitos humanos de forma global, justa e equitativa, em pé de igualdade e com a mesma ênfase. Embora particularidades nacionais e regionais devam ser levadas em consideração, assim como diversos contextos históricos, culturais e religiosos, é dever dos Estados promover e proteger todos os direitos humanos e liberdades fundamentais, sejam quais forem seus sistemas políticos, econômicos e culturais". Para uma análise mais aprofundada da Conferência e de seus resultados, conferir TRINDADE (1993, vol. 18).
} 
Os direitos fundamentais a prestações são vinculados à concepção de que ao Estado incumbe a tarefa de pôr à disposição os meios materiais e de implementar as condições fáticas que possibilitem o efetivo exercício das liberdades fundamentais. Essas prestações enquadram-se no âmbito dos assim denominados direitos humanos de segunda dimensão, correspondendo à evolução do Estado de Direito, de matriz liberal-burguesa, para o Estado democrático e social de Direito. ${ }^{22}$ Os direitos fundamentais a prestações objetivam, em última análise, à garantia do bem-estar social por intermédio do Estado, dependendo em muito de uma postura ativa dos poderes públicos para assegurar e garantir esses direitos, que envolvem, dentre outros, saúde, educação, assistência, trabalho e moradia adequada (SARLET, 2001, p. 15).

Deste modo, um dos aspectos sempre recorrentes para sustentar a pretensa distinção dos direitos civis e políticos (direitos de primeira dimensão) em relação aos econômicos, sociais e culturais (direitos de segunda dimensão) é o suposto caráter de obrigatoriedade negativa dos direitos de defesa que se dirigem, em princípio, a uma posição de respeito e abstenção por parte dos poderes públicos, enquanto os direitos econômicos, sociais e culturais, de modo geral, exigem uma postura ativa do Estado, no sentido de que este se encontra obrigado a colocar à disposição dos indivíduos prestações de natureza jurídica e material (fática) que, na maioria dos casos, implicam em considerações orçamentárias do erário público (ABRAMOVICH, 2005, p. 189).

\section{CUSTOS DOS DIREITOS. A FALSA DICOTOMIA: DIREITOS POSITIVOS VERSUS DIREITOS NEGATIVOS. DIREITOS FUNDAMENTAIS COMO DIREITOS POSITIVOS}

Com base no exposto até aqui, estabelece-se uma distinção entre dois grandes grupos de direitos: os direitos fundamentais na condição de direitos negativos (de defesa), que apresentam correspondência com os direitos humanos de primeira dimensão (direitos civis e políticos); e os direitos fundamentais como direitos positivos (a prestações de natureza fática e jurídica), correspondentes aos direitos humanos de segunda dimensão (direitos sociais, econômicos e culturais).

Em sentido oposto, a compreensão proposta dos custos dos direitos neste trabalho culmina na superação da tradicional tipologia positivo/negativo dos direitos fundamentais, reconhecendo que todos os direitos fundamentais (e não apenas os sociais) são positivos e, portanto, demandam algum tipo de prestação pública para sua efetivação, sendo afetados pela ausência de recursos e, por consequência, constituem-se em frutos de uma opção político-social.

\footnotetext{
${ }^{22}$ Para melhor compreender essa transição do Estado liberal em direção ao Estado social e democrático de direito, cf. item 2 desse trabalho: Direitos Sociais como Direitos Subjetivos.
} 
Como primeiro argumento, é relevante -principalmente a partir da constatação de que os direitos fundamentais assumem, na ordem constitucional, um duplo aspecto: jurídico-objetivo e jurídico-subjetivo- ${ }^{23}$ que se tenha presente a inevitável e incontornável co-implicação e complementação que têm os direitos fundamentais em suas diversas dimensões, o que impõe a percepção de que a dualidade direitos positivos/direitos negativos possui apenas um valor didático, posto que não devemos perceber as dimensões como instâncias estanques ou independentes entre si.

Cabe, aqui, a reprodução do seguinte trecho do artigo de CASARIN, que busca demonstrar a interdependência dos direitos fundamentais através de um exemploteórico:

[...] A caracterização das liberdades positiva e negativa é por demais elusiva: suas fronteiras não são claras, as categorias têm a flexibilidade que cada circunstância exige-lhes [...] $\mathrm{A}$ privação de direitos civis a determinado grupo (majoritário ou minoritário) necessita apoiarse na privação dos direitos políticos. Isso só é facilitado se esse grupo encontrar-se em situação de fragilidade econômica séria, portanto sem o gozo de direitos econômicos e sociais. Assim, as múltiplas constrições sobre a liberdade individual somam-se e complementam-se. Violações de liberdades raramente vêm isoladas umas das outras (CASARIN, 2008, p. 293).

$\mathrm{Na}$ doutrina e jurisprudência, de uma maneira generalizada, persiste o entendimento dicotômico que os direitos de liberdade são, em todos os casos, direitos negativos, exigindo para a sua concretização apenas uma limitação da atividade do Estado, por meio da proibição de sua atuação em algumas áreas, podendo, assim, ser assegurados juridicamente, independentemente da alocação de recursos humanos e materiais e, portanto, independentemente das circunstâncias econômicas. Já no caso dos direitos sociais, econômicos e culturais, o Estado deve necessariamente prestar os serviços exigidos, de forma positiva, diretamente vinculada a criação, destinação, distribuição e redistribuição de serviços e bens materiais, ressaltando os custos desses direitos (SARLET, 2001, p.23).

Esse modo de encarar os direitos fundamentais denota desconhecimento e/ou uma visão distorcida do papel e do funcionamento da máquina estatal que, em razão de sua formação e construção liberal, teve sua estrutura direcionada para garantir apenas os direitos de primeira dimensão, notadamente para proteção da autonomia de vontade e da propriedade privada. Dessa forma, os custos não são claramente visualizados nesse caso, pois toda máquina jurídico-burocrática e política, bem como o sistema econômico-produtivo, estão estruturados e conformados para a concretização e proteção dos denominados direitos de liberdade. Ao fim e ao cabo, os direitos de liberdade são apresentados como pressupostos da estrutura do Estado de Direito, de modo que os custos desses direitos não são visíveis ou claramente identificados, pois integram o custo da manutenção da própria máquina estatal.

${ }^{23}$ Ver tópico 1: Direitos Fundamentais como Direitos Objetivos e Subjetivos. 
Porém, tanto a estrutura dos direitos civis e políticos, como dos direitos econômicos, sociais e culturais, compreende um complexo de obrigações negativas e positivas do Estado. Nesse diapasão, em que pese extensa, entende-se por bem transcrever a consideração de Victor ABRAMOVICH e Christian COURTIS a este respeito:

[...] Los derechos civiles no se agotan en obligaciones de abstención por parte del Estado: exigen conductas positivas, tales como la reglamentación - destinada a definir el alcance y las restricciones de los derechos - la actividad administrativa de regulación, el ejercicio Del poder de policía, la protección frentea las interferencias ilícitas del propio Estado y de otros particulares, la eventual imposición de condenas por parte del Poder Judicial en caso de vulneración, la promoción del acceso al bien que constituye el objeto del derecho. [...] Em sentido simétrico, los derechos sociales tampoco se agotan en obligaciones positivas: al igual que en el caso de los derechos civiles, cuando los titulares hayan ya accedido al bien que constituye el objeto de esos derechos - el Estado tiene la obligación de abstenerse de realizar conductas que lo afecten. El Estado afectará el derecho a la salud, o a la vivienda, o a la educación, cuando prive ilícitamente a sus titulares del goce del bien del que ya disponían, sea dañando su salud, excluyéndolos de los beneficios de la seguridad social o de la educación [...] Todo derecho, entonces, requiere para su efectividad obligaciones positivas y negativas (2003, p. 137-138).

A faceta que se expressa com mais visibilidade para a primeira dimensão de direitos está no dever do Estado de se abster de atuar em certos âmbitos, sem se levar em conta que há inúmeras obrigações (positivas) que o mesmo Estado deve realizar uma série de funções para garantir e proteger esses direitos, no sentido de impedir que sejam prejudicados por outros cidadãos, bem como pelo próprio poder público. Para a segunda dimensão de direitos, as obrigações positivas são o aspecto mais relevante para identificá-la. Contudo, não é difícil descobrir, quando se observa a estrutura desses direitos, a existência concomitante de obrigações de não fazer: o direito à saúde compreende a obrigação estatal de não prejudicar a saúde; o direito à educação pressupõe a obrigação de não piorar a educação. (ABRAMOVICH, 2005, p. 191). Sob essa perspectiva, os direitos fundamentais de primeira dimensão se distinguem dos de segunda dimensão mais em uma questão de grau (eficácia e efetividade), resultado de uma construção política e não de haver diferenças essenciais entre eles.

Para melhor visualizar o equívoco da referida distinção, cabe o exemplo sobre o direito de propriedade, exposto por LIMA em sua dissertação demestrado:

Sem dúvida, uma das garantias decorrentes do direito de propriedade compreende a proibição de violação da propriedade pelo Estado, salvo mediante regular processo expropriatório, com prévia e justa indenização, o que denota uma característica negativa desse direito (o Estado não pode confiscar a propriedade particular). No entanto, a sua plena proteção exige também inúmeras obrigações positivas: promoção de um adequado aparato policial para proteger a propriedade privada (segurança pública), edição de normas para garantir o exercício do direito, estabelecimento de medidas normativas e processuais adequadas para garantir a reparação do dano no caso de violação do direito de propriedade etc. Ou seja, não basta o Estado ficar inerte, sem gastar nada, para garantir o direito de propriedade. Pelo contrário. A proteção da propriedade exige o dispêndio de grande soma de dinheiro, sob pena de tornar a propriedade alvo fácil de criminosos (LIMA, 2005, p.61). 
Buscando retratar a distinção (de grau) entre os diversos direitos fundamentais, ABRAMOVICH expõe em seu trabalho a teoria de autores como Van HOOF ou Asbjorn EIDE, em transcrição ipsis litteris:

[...] propõem um esquema interpretativo que consiste em assinalar 'níveis' de obrigaçoes estatais que caracterizariam o complexo identificador de cada direito, independentemente de atribuí-lo ao conjunto de direitos civis e políticos ou ao de direitos econômicos, sociais e culturais. De acordo com a proposta de van Hoof, por exemplo, seria possível discernir quatro 'níveis:' obrigações de respeitar, de proteger, de garantir e de promover o direito em questão. As obrigações de respeitar se definem pelo dever do Estado de não interferir nem obstaculizar ou impedir o acesso ao desfrute dos bens que constituem o objeto do direito. As obrigações de proteger consistem em evitar que terceiros interfiram, obstaculizem ou impeçam o acesso a esses bens. As obrigações de garantir pressupõem assegurar que o titular do direito tenha acesso ao bem quando não puder fazê-lo por si mesmo. As obrigações de promover se caracterizam pelo dever de criar condições para que os titulares do direito tenham acesso ao bem (apud ABRAMOVICH, 2005, p. 194-195).

$\mathrm{Na}$ mesma esteira, assume relevo a teoria dos juristas norte-americanos Stephen HOLMES e Cass R. SUNSTEIN exposta em sua obra, com o sugestivo e autoexplicativo título The Cost of Rights: why liberty depends on taxes, sintetizada por Flávio GALDINO (2005, p. 199-235) em sua obra Introdução à teoria dos custos dos direitos: direitos não nascem emárvores.

Os autores mencionados, para construção de seu raciocínio jurídico, partem da premissa equivocada de que direitos fulcrados diretamente na liberdade seriam puramente negativos, para demonstrar a tese de que todos os direitos (inclusive os tipicamente individuais) são positivos e, portanto, demandam algum tipo de prestação pública para sua efetivação, bem como considerações orçamentárias, sendo a concretização de um ou outro direito fruto de uma opção político-social.

As razões justificantes para sustentar a premissa exposta acima partem da crença que a aparente ausência de custos na proteção de alguns direitos permite a consagração de uma orientação conservadora de proteção máxima de tais direitos (normalmente os estritamente individuais: liberdade e propriedade) em detrimento dos chamados sociais, descortinando uma opção ideológica encobertada pela ignorância, havendo assim um receio velado de que a consciência e as discussões acerca dos custos dos direitos diminuam o comprometimento com a respectiva proteção (GALDINO,2005).

Os mencionados juristas demonstram que os direitos tipicamente individuais não existem sem prestações estatais positivas, pois dependem de um acervo normativo de vários níveis hierárquicos (leis, regulamentos, portarias etc.) de criação perene por parte de agentes públicos, bem como a proteção geral desses direitos depende cotidianamente da atuação de agentes governamentais (policiais, bombeiros, fiscais), sendo todos esses agentes mantidos pelo Erário, por força da arrecadação de tributos. Ademais, os titulares desses direitos dispõem de instrumentos jurídicos, evidentemente de natureza positiva, para respectiva proteção específica em face de eventuais violações. Dessa forma, a teoria dos autores norte-americanos postula que tanto os direitos positivos quanto os negativos demandam recursos, pois exigem uma atuação do Estado, que é 
intrinsecamente dependente da cobrança de tributos, primordial fonte de renda de qualquer Administração Pública (GALDINO, 2005).

Com base no exposto, a mencionada dicotomia entre direitos sem custo e direitos que custam não cumpre outro propósito senão o de encobrir os fundamentos de justiça distributiva que o país adota, de forma a manter, sob a falsa aparência da neutralidade, os critérios jurídicos tradicionais de distribuição dos bens sociais, favorecendo uma parte seleta dos indivíduos em detrimento dosdemais.

\section{CUSTOS DOS DIREITOS: A RESERVA DO POSSÍVEL VERSUS O MÍNIMO EXISTENCIAL}

Não havendo como adentrar -em face dos estreitos limites deste estudo- nos mais diferenciados aspectos sobre a teoria dos custos dos direitos, sendo também inviável considerar as principais concepções e argumentos desenvolvidos sobre a temática na doutrina e na jurisprudência, prioriza-se neste tópico o que consideramos representar a principal construção teórica (com consequências práticas) no campo dos custos dos direitos, a reserva (econômica) do possível. Além disso, faremos alguns delineamentos acerca do mínimo existencial, não perdendo de vista o enfrentamento da eficácia e da efetividade dos direitos fundamentais nas suas dimensões negativa (defensiva) e positiva (prestacional), mais especificamente, na esfera dos direitos fundamentais sociais.

A construção teórica da reserva do possível tem origem na Alemanha, notadamente a partir do início dos anos 1970, traduzindo-se na concepção de que a efetividade dos direitos fundamentais a prestações materiais estaria sob a reserva de capacidades materiais do Estado, ou seja, da dependência da real disponibilidade de recursos econômicos, localizada no campo de atuação discricionária das decisões administrativas e parlamentares. Tais noções, bem como a nomenclatura que se confere ao instituto, foram acolhidas e desenvolvidas na jurisprudência do Tribunal Constitucional Federal da Alemanha, especialmente em um caso emblemático, que ficou conhecido como numerus clausus, versando sobre o direito de acesso ao ensino superior, em que se firmou o entendimento no sentido de que os direitos a prestações somente seriam exigíveis em relação àquilo que o indivíduo, razoavelmente, pudesse esperar da sociedade, impossibilitando exigências superiores a um limite básico social (SARLET; FIGUEIREDO, 2007, p. 188-189).

No Brasil, verifica-se que a incorporação do mencionado instituto do direito estrangeiro ao ordenamento jurídico pátrio ocorreu sem qualquer procedimento de filtragem ou adaptação que levasse em consideração o contexto sócio-político-econômico brasileiro. Dessa forma, na doutrina e jurisprudência majoritária, a reserva do possível alargou seu âmbito de influência, traduzindo-se em verdadeiro obstáculo a 
proteger o poder público de ter que cumprir com os deveres aos quais está constitucionalmente submetido, notadamente no que se refere à efetivação dos direitos fundamentais prestacionais de dimensãosocial. ${ }^{24}$

Apesar de a reserva do possível, aparentemente, ostentar o caráter de limitação lógico-jurídica e fática para efetivação dos direitos fundamentais em geral, não há como desconsiderar a banalização no seu discurso para obstar a concretização dos direitos socioeconômicos, ressaltando a dimensão economicamente relevante desses direitos que, embora comum a todos os direitos fundamentais de todas as dimensões, acaba assumindo particular relevância quando se cuida da efetivação dos direitos a prestações (SARLET; FIGUEIREDO, 2007, p. 186).

Como já demostrado, na esteira da obra de HOLMES e SUNSTEIN e de acordo com a posição entre nós sustentada por autores como Ingo SARLET e Flávio GALDINO, todos os direitos fundamentais são direitos prestacionais, inclusive os direitos de primeira dimensão, que exigem, para que sejam efetivados, um conjunto de medidas positivas que envolvem a alocação significativa de recursos materiais e humanos para proteger, assegurar e garantir tais direitos. Deste modo, a defesa corrente da irrelevância econômica dos direitos de primeira dimensão demonstra, na verdade, uma opção político-ideológica pela concretização de tais direitos, bem como se constitui uma forma de manter, sob a falsa aparência da neutralidade, os critérios jurídicos tradicionais de alocação de recursos e distribuição de bens.

Ademais, a simples alegação de uma reserva do possível, sem apresentar elementos concretos a respeito de haver, de fato, impossibilidade material para a prestação de um direito, pode levar a uma aniquilação, pela via interpretativa, dos direitos sociais reconhecidos pela Constituição. Dessa forma, não basta simplesmente alegar que não há possibilidades financeiras para concretizar os direitos fundamentais; é necessário demonstração cabal da mencionada impossibilidade fática, sob pena de nulificação dos direitos sociais (SALDANHA, 2009, p.15).

Em sentido contrário à reserva do possível, alguns estudiosos pátrios, inspirados pelas doutrina e jurisprudência alemãs, têm se preocupado em defender a primazia de um conjunto de direitos necessários a uma existência digna e ao exercício de liberdades básicas, por meio da construção do chamado mínimo existencial, também denominado de mínimo essencial ou mínimo necessário a uma existência condigna, entre outras nomenclaturas. Trata-se, na verdade, de reconhecer um núcleo essencial dos direitos fundamentais que se constitui em direito subjetivo definitivo a uma parcela das prestações positivas consideradas indispensáveis (alimentação, vestimenta, abrigo, saúde, educação básica etc.) para a vida com mínima dignidade e para o exercício dos direitos de liberdade (GALDINO, 2005, p. 195).

\footnotetext{
${ }^{24}$ Nesse sentido, SARLET e FIGUEIREDO (2007, p.189) identificando a condição assumida pela reserva do possível como limite fático e jurídico para a efetivação dos direitos fundamentais; visualizam três aspectos do referido instituto: a) disponibilidade fática de recursos (reserva do possível econômica); b) disponibilidade jurídica de recursos materiais e humanos, que se refere tanto à distribuição das receitas e competências tributárias, orçamentárias, legislativas e administrativas (reserva do possível jurídica), como ao poder jurídico (capacidade jurídica) de disposição de tais recursos; e c) a proporcionalidade na prestação.
} 
Nesta seara, destaca-se a contribuição de Ricardo Lobo TORRES que, além de discorrer sobre o enquadramento do mínimo existencial no âmbito dos direitos de primeira dimensão (direitos de liberdade), identificou um duplo aspecto de tal conceito: a) proteção negativa, que impossibilita a atuação do Estado no que tange à incidência tributária sobre os direitos sociais mínimos; e b) proteção positiva representada por prestações materiais que visam à preservação da liberdade (TORRES, 2003, p. 1-2).

De acordo com SARLET e FIGUEIREDO (2007, p.179), o mínimo existencial está garantido, em primeiro lugar, por ser pressuposto do princípio da dignidade humana, pois esta não estaria garantida apenas pela proteção das liberdades individuais, mas também por "um mínimo de segurança social, já que, sem os recursos materiais para uma existência digna, a própria dignidade humana ficaria sacrificada”; em segundo lugar, estaria garantido como condição dos direitos à vida e à integridade física, que pressupõem uma postura ativa na sua proteção e, por fim, no direito geral de liberdade, já que a qualidade de pessoa autônoma e responsável não prescinde da garantia de condições mínimas de existência.

Apesar do avanço na formulação do instituto do mínimo existencial, notadamente como mecanismo jurídico para confrontar e/ou suavizar as restrições impostas pela reserva do possível, é evidente que há uma série de aspectos problemáticos. Primeiramente, quanto ao conteúdo e alcance do próprio mínimo existencial, que não se pode ser quantificado de uma forma única e definitiva, pois ele varia conforme o contexto espacial e histórico, a esfera econômica e financeira, a condição individual e familiar, bem como o padrão valorativo vigente em uma sociedade (SARLET; FIGUEIREDO, 2007, p. 186), que gera como consequência a dificuldade de operacionalização de tal instituto, pois não cria parâmetros claros para a tomada de decisão de legisladores, administradores ou juízes, tampouco para seu controle social, já que a delimitação (conteúdo e extensão) do mínimo existencial fica relegada ao casuísmo e a variáveis circunstanciais (WANG, 2009, p. 314-315).

Em segundo lugar, questiona-se a pertinência do conceito de mínimo existencial a respeito da justiciabilidade dos direitos sociais: ao se pretender deslocar as discussões acerca da efetividade dos direitos culturais, econômicos e sociais para dentro da dicotomia reserva do possível versus mínimo existencial, quer-se na verdade transformar os direitos de segunda dimensão em um núcleo mínimo de prestações materiais que apenas garantem o exercício dos direitos de primeira dimensão (TORRES, 2003). Por outro lado, para além do fato de que o critério do mínimo existencial -como parâmetro de reconhecimento de direitos subjetivos a prestações materiais- por si só já contribui para relativizar a reserva do possível, há que se explorar outras possibilidades que, somadas e bem utilizadas, poderão reduzir, se não até mesmo neutralizar, o seu impacto. ${ }^{25}$

\footnotetext{
${ }^{25}$ Nesse contexto, há de se decidir sobre a aplicação dos recursos materiais necessários à satisfação dos direitos sociais: quanto mais diminuta a disponibilidade de recursos, mais se impõe uma deliberação responsável e democrática a respeito de sua destinação, o que nos remete diretamente à necessidade de aprimorar os mecanismos de gestão democrática e participativa do orçamento público, bem como do próprio processo de administração de políticas públicas. Impõe-se o controle judicial das opções
} 
Embora a reserva do possível de fato obste a prestação de direitos em uma situação em que simplesmente não existam recursos, o mero argumento de ausência orçamentária não impede o Poder Judiciário de zelar pela efetivação dos direitos fundamentais sociais, pois a inafastabilidade do controle jurisdicional prevista na Constituição Federal dá aos juízes poder para tutelar qualquer lesão ou ameaça a direito, ainda que decorrentes de políticas públicas ou da ausência delas. ${ }^{26}$

A maior atuação do Poder Judiciário em matéria de concretização de direitos fundamentais (notadamente os sociais) está diretamente relacionada com a existência de fatores políticos, tais como debilidade das instituições democráticas de representação, bem como a deterioração dos espaços tradicionais de mediação social e política, que contribuíram para atribuir à esfera judicial uma especial legitimação para ocupar novos espaços de decisão, anteriormente restritos aos demais poderes do Estado. Porém, cabe a ressalva que esse ativismo judicial deve ser exercido com cautela e responsabilidade, consciente do problema da escassez de recursos e sem ignorar a necessidade de uma autolimitação funcional (teoria do self-restraint) por parte dos magistrados, que não implique necessariamente em violação do princípio democrático e do princípio da repartição dos poderes (ABRAMOVICH, 2005, p.204-205).

Assim, em um sistema político-institucional com fortes falhas, bem como um contexto marcado por enormes desigualdades econômicas e gravíssimas mazelas sociais, além de um sistema jurídico anacrônico, nem as vitórias judiciais em matéria de direitos sociais nem os triunfos políticos são definitivos, e impõem a utilização de todos os mecanismos de reivindicação e de atuação disponíveis. A articulação das ações jurídico-institucionais somado a outras estratégias de incidência política será a chave de uma estratégia efetiva de exigibilidade dos direitos sociais, econômicos e culturais.

\section{A GUISA DE CONCLUSÃO}

Por esta pesquisa, não tivemos a pretensão de versar sobre a teoria dos custos dos direitos em toda sua amplitude e profundidade. O que aqui se buscou foi, tão-somente, identificar que essa teoria, apresentada como realista, pois baseada em argumentos relativos a escassez de recursos e subordinação dos direitos às condições econômicas reais da sociedade, é essencialmente idealista, cuja principal finalidade, antes de descrever o direito, é

recursos disponíveis) para adequá-los às prioridades constitucionais, mais especificamente a efetividades dos direitos fundamentais (SARLET; FIGUEIREDO, 2007, p. 190 e 195).

${ }^{26}$ Cabe destacar um trecho de artigo em que o autor sintetiza com maestria as diversas possibilidades de atuação do Poder Judiciário no que tange aos direitos fundamentais sociais: "Vimos como a margem de atuação do Poder Judiciário pode variar consideravelmente, de acordo com as ações de exigibilidade direta de direitos econômicos, sociais e culturais - legalizar uma decisão de política pública já assumida pelo Estado; executar uma lei ou uma norma administrativa que determina obrigações jurídicas em matéria social; estabelecer um padrão dentro do qual a administração deva planejar e implementar ações concretas e supervisionar sua execução; determinar uma conduta a seguir; ou, em certos casos, constituir em mora o Estado em relação a uma obrigação, sem impor um remédio processual ou uma determinada medida de execução [...]." (ABRAMOVICH, 2005, p. 209210). 
promover sua estruturação segundo um determinado projeto social que prestigie tão-somente a preservação de direitos abstratos, sem efetividade social.

A efetividade dos direitos humanos depende, entre outros fatores, de seu reconhecimento pelo Estado, o que se dá em regra por meio de sua positivação. Ao serem incluídos no ordenamento jurídico, esses direitos morais tornam-se direitos fundamentais, válidos e exigíveis. Deve-se reconhecer, no entanto, que a incorporação desses direitos ao ordenamento ocorre em razão de construção intelectual e valorativa desenvolvida a partir de processos históricos de correlação de forças dos grupos sociais de determinada sociedade. Tanto é que os direitos que são definidos como fundamentais são apenas aqueles que resultaram desse embate, assim como é esse conflito que determina a extensão da efetividade de cadaum dos direitos positivados.

A própria discussão sobre as perspectivas jurídico-objetiva (mandamentos de otimização) e jurídicosubjetiva (direitos públicos subjetivos) dos direitos fundamentais, considerados entendimentos complementares e interrelacionados, podem ser entendidos dentro desse embate pela efetivação de alguns direitos, mas não de outros, sempre conforme o processo histórico de lutas sociais (aliás, confirmando o que já dizia Ihering, o direito não acontece sem luta).

Pelo processo histórico do desenvolvimento social, é possível entender a passagem do Estado liberal para o Estado social de Direito. Aquele, estruturado em grande medida pelos interesses quase exclusivos da burguesia revolucionária, elevava os direitos de primeira dimensão ou negativos como os únicos "verdadeiros" direitos do homem. Direitos abstratos para a maioria das pessoas, porém instrumentos concretos e efetivos para o desenvolvimento do projeto político desse grupo social. O Estado social, entre outros motivos por causa da desagregação social (veja, por exemplo, a situação dos estados ocidentais na década de 1930, após o crack da bolsa de Nova York), e das demandas dos grupos mais populares por melhores condições de vida, passou a promover os direitos de segunda dimensão ou positivos. Não obstante, esse processo por efetivação de direitos é ininterrupto: em todo Estado liberal há grupos sociais interessados na consolidação de direitos sociais, e em todo Estado social há grupos interessados na preservação quase exclusiva dos direitos individuais. Neste último caso, uma das formas de legitimar a descaracterização dos direitos sociais como fundamentais é, exatamente, a teoria dos custos dos direitos.

Apesar de os direitos sociais serem considerados como direitos fundamentais subjetivos (o que, em tese, eliminaria qualquer embargo teórico-jurídico para a sua concretização), a construção do princípio da reserva econômica do possível apresenta-se, no âmbito da teoria dos custos dos direitos, como o principal óbice à efetividade dos direitos sociais, já que condiciona esta à disponibilidade orçamentária. Porém, não condiciona os direitos individuais ao orçamento, justamente por fazer distinção entre eles: os direitos civis e políticos (direitos de 
primeira dimensão) teriam apenas uma misteriosa obrigatoriedade negativa, um dever de simples abstenção, ao contrário dos direitos econômicos, sociais e culturais (direitos de segunda dimensão), estes sim gerariam custos.

A reserva do possível, principal argumento da teoria dos custos dos direitos, é refutado por meio do rompimento com a tradicional tipologia positivo/negativo dos direitos. Isso é perfeitamente possível por se constatar que todos os direitos fundamentais demandam prestações do Estado e comprometem o orçamento: os direitos de primeira dimensão também exigem, para que sejam efetivados, um conjunto de medidas positivas que envolvem a alocação significativa de recursos materiais e humanos para proteger, assegurar e garantir tais direitos. Aliás, os recursos orçamentários de praticamente todos os países ocidentais, o Brasil inclusive, estão quase que totalmente comprometidos com a prestação de serviços estatais de preservação dos direitos individuais, e não dos sociais. À guisa de exemplo, polícia, justiça e burocracia são três funções estatais altamente relevantes para a promoção e garantia dos direitos individuais, que não teriam condição de serem efetivos sem a presença desse suporte estatal.

Dessa forma, a mencionada dicotomia não cumpre outro propósito senão o de encobrir os fundamentos de justiça distributiva que o país adota, de forma a manter sob a falsa aparência da neutralidade os critérios jurídicos tradicionais de distribuição dos bens sociais, favorecendo uma parte seleta dos indivíduos em detrimento dos demais. Dessa forma, os custos não são claramente visualizados na efetivação dos direitos de primeira dimensão, pois toda máquina jurídico-burocrática e política, bem como o sistema econômico-produtivo, estão estruturados e conformados para a concretização e proteção dos denominados direitos deliberdade.

\title{
ON THE THEORY OF COST OF RIGHTS
}

\begin{abstract}
This paper aims to discuss on the theory of the costs of rights with respect to fundamental rights. In accordance with this theory, there is no rights if it lacks the resources necessary for their promotion. In an environment of scarcity and of unlimited human needs, one should adequately manage the allocation of available resources. It is said, by this theory, that some fundamental rights, that is the individual rights, do not generate costs for being implemented, and thus the scarcity prevents from implementing social rights only. However, a realistic approach on Law identifies that any right needs resources for being effective, which refutes the theory of costs of rights because it becomes clear that the aim of such theory is not exactly to describe Law, but to subordinate it to a certain form of social organization that promotes certain rights but notothers.
\end{abstract}

Keywords: Cost of Rights. Fundamental Social Rights. Positive/Negative Rights. Under the reserve of possibilities clause. Existential Minimum. 


\section{REFERENCIAS BIBLIOGRÁFICAS}

ABRAMOVICH. Victor. Linhas de trabalho em direitos econômicos, sociais e culturais: instrumentos e aliados. SUR - Revista Internacional de Direitos Humanos, ano 2, nº 2, 2005, p. 188-223.

ABRAMOVICH. Victor; COURTIS. Christian. Apuntes sobre la exigibilidad judicial de los derechos sociales. In: SARLET, Ingo W. (org.). Direitos Fundamentais Sociais: Estudos de Direito Constitucional, Internacional e Comparado. Rio de Janeiro: Renovar, 2003, p. 135-167.

ÁVILA, Humberto. Teoria dos princípios: da definição à aplicação dos princípios jurídicos. 13. ed. rev. e ampl. São Paulo: Malheiros, 2012.

BARRETO, Vicente de Paulo. Reflexões sobre os Direitos Sociais. In: SARLET, Ingo W. (org.) Direitos Fundamentais Sociais: Estudos de Direito Constitucional, Internacional e Comparado. Rio de Janeiro: Renovar, 2003, p. 107-134.

BOBBIO, Norberto. A Era dos Direitos. Trad. Carlos Nelson Coutinho. Rio de Janeiro: Campus, 1992. O Positivismo Jurídico: Lições de Filosofia do Direito. São Paulo:Ícone, 1995.

BONAVIDES, Paulo. Curso de direito constitucional. 25. ed. São Paulo: Malheiros, 2010.

BORGES. Rodrigo Lanzi de Moraes. O conceito de princípio: uma questão de critério. Revista Direitos Fundamentais e Democracia, vol. 7, n. 7. Unibrasil: Curitiba, 2010, p.247-269.

BRASIL. Constituição (1988). Constituição da República Federativa do Brasil. Brasília: DF, Senado, 1998.

CASARIN. Júlio Cesar. Isaiah Berlim: afirmação e limitação da liberdade. Revista de Sociologia Política, vol. 16, n 30. Curitiba, 2008, p.283-295.

CHAVES. Pablo Bonilla. O Custo dos Direitos e sua Relação com as Restrições Jusfundamentais: Aspectos Gerais sobre o Caso brasileiro. Revista Direitos Fundamentais e Democracia, vol. 4, Unibrasil: Curitiba, 2008, p. $1-39$.

COMPARATO. Fábio Konder. A Afirmação Histórica dos Direitos Humanos. 7 ed. rev. e atual. São Paulo: Saraiva, 2010.

DUARTE, Clarice Seixas. Direito Público Subjetivo e Políticas Educacionais. São Paulo em Perspectiva, n. 18(2): São Paulo, 2004, p. 113-118.

GALDINO, Flávio. Introdução à Teoria dos Custos dos Direitos: Direitos Não Nascem Em Árvores. Rio de Janeiro: Lumen Juris, 2005.

HIERRO, Liborio Luis. ¿Qué derechos tenemos? Revista Doxa, nº 23, 2000, p.351-375.

KELSEN, Hans. Teoria pura do direito. Trad. João Baptista Machado. São Paulo: Martins Fontes, 2003.

KOERNER, Andrei. Ordem Política e Sujeito de Direito no Debate sobre Direitos Humanos. Revista Lua Nova, n. 57,2002, p. 87-111. 
Andrei. O Papel dos Direitos Humanos na Política Democrática: uma análise preliminar. Revista Brasileira de Ciências Sociais, vol. 18, n. 53, 2003, p. 143-158.

LIMA. George Marmelstein. Efetivação Judicial dos Direitos Econômicos, Sociais e Culturais. Dissertação de Mestrado. Universidade Federal do Ceará: Fortaleza, 2005.

MASTRODI, Josué. Sobre o real fundamento dos direitos fundamentais. Revista Digital de Direito Público, vol. 1, n. 1,2012, p. 150-187.

MASTRODI, Josué. Ponderação de direitos e proporcionalidade das decisões judiciais. Revista Direito GV, vol. 10, n. 2, 2014, p. 577-596.

MELlO, Celso Antônio Bandeira de. Eficácia das Normas Constitucionais de Direitos Sociais, São Paulo: Malheiros, 2009.

PNUD. Relatório de Desenvolvimento Humano 2010. A Verdadeira Riqueza das Nações: Vias para o Desenvolvimento Humano. Nova York, 2010. Disponível em: http://mirror.undp.org/angola/LinkRtf/HDR_2011_PT.pdf. Acesso em07/08/2015.

SALDANHA, Ana Claudia. A interpretação constitucional dos direitos sociais e o mínimo existencial. Revista acadêmica da ESMP. Fortaleza, ano 1, n.1, 2009. Disponível em: http://www.pgj.ce.gov.br/esmp/publicacoes/edl/artigos/intrepretacao.constitucional.dos.direitos.sociais.pdf. Acesso em: 07/08/2015, p.1-20.

SANTOS, Boaventura de Souza. Por uma concepção multicultural de direitos humanos. Reconhecer para libertar. Os caminhos do cosmopolitismo multicultural. Revista Lua Nova, n. 39, 1997, p. 105-124.

SARLET, Ingo Wolfgang; FIGUEIREDO, Mariana Filchtiner. Reserva do possível, mínimo existencial e direito à saúde: algumas aproximações. Revista Direitos Fundamentais e Justiça, n. 1, 2007, p. 171-213.

SARLET, Ingo Wolfgang. A Problemática dos Fundamentais Sociais como Limites Materiais ao Poder de Reforma da Constituição. In: SARLET, Ingo W. (org.). Direitos Fundamentais Sociais: Estudos de Direito Constitucional, Internacional e Comparado. Rio de Janeiro: Renovar, 2003, p.333-394.

Ingo Wolfgang. Os direitos fundamentais sociais na Constituição de 1988. Revista Diálogo Jurídico, ano I, vol. I, n. 1. Salvador, 2001, p. 1-46.

SILVA, José Afonso da. Aplicabilidade das normas constitucioanis, 7a ed. São Paulo: Malheiros,2009.

TORRES, Ricardo Lobo. A metamorfose dos Direitos Sociais em Mínimo Existencial. In: SARLET, Ingo W. (org.). Direitos Fundamentais Sociais: Estudos de Direito Constitucional, Internacional e Comparado. Rio de Janeiro: Renovar, 2003, p. 1-46.

TRINDADE, Antônio Augusto Cançado. Balanço dos resultados da Conferência Mundial de Direitos Humanos: Viena, 1993. Revista IIDH, vol. 18, 1993, p. 11-28.

WANG. Daniel Wei Liang. Resenhas - Reserva do possível, mínimo existencial e direito à saúde: algumas aproximações. Revista de Direito Sanitário, vol. 10, n. 1, São Paulo, 2009, p.308-318. 
Trabalhoenviadoem20deoutubrode2015. Aceitoem06dedezembrode2015. 